\title{
Child Maltreatment and the Advocacy Role of Professional School Counselors
}

\author{
Kathleen Marie Barrett, Susan V. Lester, and Judith C. Durham \\ Saint Joseph College
}

\begin{abstract}
Recent focus in counseling has been on the expansion of advocacy to disadvantaged and marginalized populations. Utilizing advocacy dispositions and competencies, this article details the school counselor's role in working with maltreated children. Examples are cited for advocacy work at the individual child, school, and broader social levels.
\end{abstract}

Keywords : advocacy, child maltreatment, school counselor, abuse, social justice

The role of the professional school counselor has undergone dramatic transformation over the last decade, reshaped by The ASCA National Model: A Framework for School Counseling Programs (American School Counseling Association [ASCA], 2005) and its interrelated themes of leadership, collaboration, and advocacy. The last of these, advocacy, is the focus of this article.

The National Standards for Students (ASCA, 2004a; Campbell \& Dahir, 1997) direct school counselors to use their comprehensive role to promote healthy development in academic, career, and personal-social arenas, and social justice advocacy demands that counselors uphold this goal for all students. While success for all students has been prioritized in recent years (Education Trust, 2009; Erford, 2003), the reality that some populations of children come to school at a decided disadvantage is undeniable. The counselor's duty to affirm and advocate for all students, particularly for disadvantaged populations, is clearly addressed in both counseling 
and education standards (ASCA, 2004b). One such disadvantaged population, maltreated children, is identified here as being in need of advocacy by professional school counselors.

ASCA (2004b) identifies advocacy as an important ethical responsibility, and the American Counseling Association (ACA) directs counselors "to examine potential barriers and obstacles that inhibit access and/or the growth and development of clients" (2005, section A.6.a). A foundational commitment to social justice advocacy is not simply encouraged for today's professional counselor, but, according to Lee, it is "a moral imperative" requiring a transformation of the contextual vision and professional practice of the counselor, so that, as a matter of professional priority, counselors become "agents of social justice" (2007, p. 1). Today's school counselor has the task of identifying obstacles and opening doors previously closed to disadvantaged groups of our nation's children (Ratts, DeKruyf, \& Chen-Hayes, 2007). In order to do so, school counselors must move beyond interventions at an individual level to take an advocacy role, "identifying unmet needs and taking actions to change the circumstances that contribute to the problem or inequity" (Trusty \& Brown, 2005, p. 259). In the current climate of educational reform, The Education Trust (2009) affirms that it is the counselor's duty to advocate to reduce environmental and institutional barriers that impede students' academic success.

In response to growing emphasis on advocacy in the counseling profession, the ACA called for development of and subsequently endorsed a set of advocacy competencies created by Lewis, Arnold, House, and Toporek (2002) that offer a framework of interventions on a continuum ranging from the individual or micro level to the sociopolitical or macro level. The competencies distinguish between acting with or empowering a client, and acting on behalf of or advocating for an individual or group. The ACA affirmed its continuing emphasis on advocacy in a special section on advocacy competence in a recent issue of the Journal of Counseling and Development in which Goodman (2009) reviewed development of the advocacy movement in counseling. Subsequent literature has operationalized these competencies using case examples to articulate counselor's advocacy role at the student level (Ratts \& Hutchins, 2009; Marbley, Malott, Flaherty, \& Frederick, 2011), at the school and community level (Lopez-Baez \& Paylo, 2009; Marbley et al., 2001), and at the public levels (Lee \& Rodgers, 2009; Toporek, Lewis, \& Crethar, 2009; Marbley et al., 2001). Each offers a unique contribution to conceptualizing the counselor's advocacy role. This article applies a social justice-inspired advocacy perspective to the practice of school counselors working with maltreated children, a disadvantaged population at risk, for substantially poorer developmental and academic outcomes (Cole et al., 2005; Crosson-Tower, 2008; Perez \& Widom, 1994; Wodarski, Kurtz, Gaudin, \& Howling, 1990).

Application of the advocacy competencies presents a range of both challenges and opportunities. Counselors in school settings who apply a social justice lens to work with maltreated children must manage a dramatically evolving professional identity while navigating the inherent complexity within and between the systems that so characterizes child abuse prevention and intervention in school settings. As this article progresses, application of the advocacy competencies to the counselor role is illustrated in multiple practice examples demonstrating strategies that function to address within system complexity and build bridges between conflicting systems to ensure best outcomes for maltreated children. 
Finally, while the focus of this article is on the role of the professional school counselor as defined by ASCA, it is important to note that a range of mental health professionals provides services to children in school settings including clinical mental health counselors, social workers, marriage and family therapists, and school psychologists. Although differences in role and scope of practice exist, all should function as social justice advocates, especially in providing services to children who are underserved, disadvantaged, maltreated, or living in abusive situations.

\section{Child Maltreatment}

Child maltreatment, for the purpose of this article, includes physical, sexual, and psychological abuse, neglect, and exposure to family violence. It occurs across all social, economic, racial, and cultural categories. However, victims of African-American, American Indian or Alaska Native, and others of multiple racial descent have the highest rates of victimization $(15.1,11.6$, and 12.4 respectively per 1,000 children), and these proportions have remained stable for several years (Child Maltreatment, 2009). In 2006, the United States Department of Health and Human Services recorded 3.6 million reports of suspected child maltreatment (Middlebrooks \& Audage, 2008). Of the 43.7 reports per 1000 children, 12 resulted in substantiation of abuse or neglect, confirming at least $1.2 \%$ of United States children were victims of maltreatment during that year (US Department of Health and Human Services, 2006). In estimating actual rates of abuse, retrospective self-reports of childhood abuse by adults through anonymous surveys suggest numbers are actually much larger (Middlebrooks \& Audage). This is illustrated in the landmark Adverse Childhood Experiences (ACE) (Middlebrooks \& Audage) study that showed $28.3 \%$ of adults retrospectively reporting childhood histories of physical abuse, $20.7 \%$ childhood sexual abuse, and $12.7 \%$ having mothers who were victims of domestic violence. In a random sample of 26,229 adults in five states, Bynum et al. (2011) found that overall, 59.4\% of respondents reported having at least one incidence of Adverse Childhood Experience (ACE), and $8.7 \%$ reported five or more ACEs. The reported prevalence of each ACE included $29.1 \%$ for household substance abuse, one quarter (25.9\%) reported verbal abuse, $14.8 \%$ reported physical abuse, and $12.2 \%$ reported sexual abuse. In the ACE categories measuring family dysfunction, $26.6 \%$ of respondents reported having lived with separated or divorced parents; $19.4 \%$ reported that they had lived with someone who was depressed, mentally ill, or suicidal; and $16.3 \%$ reported witnessing domestic violence. It is notable that women reported significantly higher rates of sexual abuse (17.2\%) than men (6.7\%) (Bynum et al., 2011). Similarly, Arata, Langhinrichsen-Rohling, Bowers, and O'Brien (2007) found that nearly two out of three high school students reported having experienced some form of maltreatment. Based on both reported and projected unreported cases of maltreatment, Lambie (2005) estimated that at least five children in the average United States classroom either have a history of reports to child protective services or will be subjects of future reports. These reports and projections present a sobering picture. Even though, perhaps not always readily apparent, a significant population of child victims of maltreatment is present in our schools, a fact that calls for the involvement of school counselors as social justice advocates.

A substantial body of research supports the conclusion that the impact of maltreatment on the developing child can be profound, affecting both school-specific and broader life contexts, and may extend long after childhood has passed (National Clearinghouse on Child Abuse and Neglect Information, 2005). Maltreatment exerts a pervasive negative impact on development in personal, social, emotional, cognitive, and behavioral domains. Thus, maltreated children 
come to school both decidedly disadvantaged and at significant risk for a broad range of poor developmental and academic outcomes (Cole et al., 2005; Crosson-Tower, 2008; Perez \& Widom, 1994; Widom, 2000; Wodarski et al., 1990). The experience of psychological trauma often co-occurs with maltreatment, and carries with it a host of exacerbating, detrimental effects on all aspects of growth and development (Cole et al., 2005; Perry, 2001).

Children who experience maltreatment are placed at decidedly greater risk for both immediate and later negative life consequences. These include significantly higher rates of diagnosis of psychological and emotional disorders (Reynolds, Wallace, Hill, Weist, \& Nabors, 2001; Teicher, 2000); impaired brain development (Perry, 2001); cognitive capability and academic success (Pears, Kim, \& Fisher, 2008; Rowe \& Eckenrode, 1999); and increases in current and later high risk behaviors and disorders including substance use, eating disorders, promiscuity, and suicide attempts (Kaplow \& Widom, 2007; Silverman, Reinherz, \& Giaconia, 1996; Widom, Marmorstein, \& White, 2006). In a meta-analysis exploring associations between abuse and suicidal behavior in adolescents, a history of physical or sexual abuse was associated with significantly higher rates of suicidal thought and action (Evans, Hawton, \& Rodham, 2005) as well as increased risk of school drop-out and criminal behavior that childhood maltreatment increases the likelihood of arrest among juveniles by 59\% (Widom \& Maxfield, 2001). When children are exposed to violence against their mothers, there is an associated significant increase in behavioral problems in the school setting (Kernic et al., 2003) that may contribute to broader problems in academic and social development. When abuse is experienced as chronic and traumatic, more severe and longer lasting mental health effects may be observed to dramatically disrupt development (Cole et al., 2005). Notable, too, is the association between exposure to child abuse and the length of life and premature mortality (Bynum, 2011).

Given the prevalence of childhood maltreatment and the gravity of associated consequences, schools are called to view maltreated children as a population in need of advocacy, and develop systems to enable more effective recognition, prevention, and response (ASCA, 2003). As a result of both the nature and frequency of their contact with children (Hinkelman \& Bruno, 2008) and their explicit legal duty, educational professionals constitute the largest percentage of professional reporters of child abuse and neglect (U.S. Department of Health and Human Services, 2006). Often acting as the coordinators of a school's response to maltreatment, school counselors are in a unique position to effect change (Lambie, 2005). ASCA articulates the responsibilities of professional school counselors in regard to child maltreatment and views the counselor role as "a key link in the child abuse prevention network" with the opportunity to "facilitate a turning point in the life and behavior of an abusive family" (2003, para. 6). By competently recognizing and responding to child maltreatment, school counselors are functioning as social justice counselor advocates.

\section{Advocacy Dispositions and Competencies for School Counselors}

Building upon the multilevel Advocacy Competencies (Lewis et al., 2002), Ratts et al. (2007) have provided a model for conceptualizing the application of advocacy competencies to the role of the professional school counselor. These include advocacy interventions at the individual student level, the school and community level, and the broader public arena. Crethar (2010) aligns school counselor advocacy competencies with the ASCA National Model (2005) illustrating the effective use of a school counselor's multifaceted advocacy role to identify and eliminate 
obstacles for a disadvantaged population. Trusty and Brown (2005) articulate a set of advocacy dispositions, knowledge, and skills essential for school counselor advocacy competency. According to Trusty and Brown, a disposition toward advocacy reflects the personal beliefs, values, and commitments held by the counselor; and includes a sense of personal altruism, a solid grounding in ethics, a commitment to both family empowerment and social justice, and a social advocacy orientation. Application of these advocacy dispositions to maltreatment-focused work offers counselors new ways of both perceiving and utilizing their professional role effectively to meet the needs of this special population. This article incorporates all of the above advocacy conceptualizations into a focused discussion of the school counselor's advocacy role specific to the issue of child maltreatment.

\section{Advocacy Dispositions to Promote Change}

One of the essential dispositions described by Trusty and Brown (2005) is altruism, or the "unselfish regard for or devotion to the welfare of others" (altruism, 2010). Counselors disposed toward advocacy are characterized by "an altruistic motivation with the major concern being students' well-being" (Trusty and Brown, 2005, p. 260). Concern for a child's well-being, however, can be influenced by a counselor's values and personal life experiences. The ethical codes of both ACA (2005) and ASCA (2004b) as well as principles of multicultural competency (Sue, Arredondo, \& McDavis, 1992) emphasize the need to recognize those personal values, beliefs, or attitudes as they have potential to bias perception or judgment. To support healthy and realistic altruism in work with maltreated children, a counselor must be self-aware and open to exploration of personal exposure to maltreatment and resultant beliefs and values. Webster, O'Toole, O'Toole, and Lucal (2005), and Yoshihama and Mills (2003) have shown that personal life experience with maltreatment may function to predispose a professional to bias and interfere with effective recognition of and response to abuse. Given the emotionally evocative nature of work with abuse, the potential for clouding of professional judgment is especially concerning for those counselors with a personal history of maltreatment. When decisions regarding reporting must be made in the face of ambiguous circumstances, there is increased potential for personal life experience to have an impact on professional judgment. Bluestone (2005) notes this is consistent with the more general inclination to rely upon old schemata in the face of uncertainty. An advocacy disposition provides the rationale to support both self-awareness and appropriate utilization of consultation and supervision to ensure an unbiased perspective and response in work with maltreatment. Crosson-Tower (2008) makes a strong case for the value of peer supervision groups to address issues of counter transference and provide opportunities for counselors to talk about the powerful feelings that this work may evoke. Miller-Perrin and Perrin (2007) speak to the reality of vicarious traumatization and potential for counter transference among those who have personal histories of trauma and maltreatment.

For professionals who have regular contact with children, the personal life experience of maltreatment adds a layer of complexity at the deepest level. As with any transferential issue, such personal experience may add a heightened sensitivity to issues of abuse, appropriately motivate a counselor to try to make a difference for a maltreated child, or alternately function as a social justice zealot; and may have a subsequent impact on the result in the courtroom. For instance, being the recipient of a pointed cross-examination designed to demonstrate bias is 
one example of why counselors who have personal abuse histories should be cautious and consult liberally around maltreatment related decision making.

\section{Commitment to Ethics}

Trusty and Brown (2005) identify the commitment to professional ethical standards as a second major component of an advocacy disposition. Given the legal and ethical components inherent in work with maltreatment, it is essential that school counselors have both a solid knowledge base in this area and the ability to translate this knowledge into practice. School counselors with an advocacy disposition are familiar with legal, ethical, and school policy parameters and can lead coordinated school-wide maltreatment prevention and intervention programs (Lambie, 2005). In shaping policy and protocol, the counselor or advocate needs to be attentive to elements within the system that foster and sustain inequity. Trusty and Brown (2005) describe an ethical disposition as reflected in the counselors' full appreciation of their responsibility to students, families, school, and profession as well as in the use of ethical guidelines and sound decision-making protocols in the management of the ethical dilemmas.

Central to work with maltreatment and counseling practice are a number of associated legal issues, the most prominent of which is mandatory reporting of abuse. Here, in the intersection of legal and educational systems lies the potential for conflict between competing agendas and protocols. Research demonstrates that school counselors are generally aware of their duties as mandated reporters (Bryant, 2009; Walsh, Bridgstock, Farrell, Rassafiani, \& Schweizer, 2008) and consistently identify child-abuse reporting as one of their most frequently encountered ethical and legal decision-making issues (Hermann, 2002). Bryant and Milsom (2005) on a state level and Bryant (2009) on a national level explored circumstances under which counselors do and do not report abuse. Reasons cited for choosing not to report included concerns relating to insufficient proof, concerns about legal consequences, and worry that a negative result might occur for the child. Webster et al. (2005) concluded that teachers were significantly more likely to under-report than to over-report abuse and that $84 \%$ of abuse recognized in the school environment goes unreported. The potential for under-reporting in school settings is strong, suggesting that the gap that separates actual incidence from reported incidence, which Miller-Perrin and Perrin (2007) call the "black figure," is substantial. Lambie (2005) advocates for a coordinated school response that can provide a mechanism to better evaluate reporting decisions. The degree to which this under reporting may be influenced by personal histories of abuse is unknown. From an ethical perspective, school counselors are charged with serving the student, family, school, and broader community (ASCA, 2004b), and all members have needs that could be met by school counselor advocates reporting incidences of potential abuse and maltreatment. Stone (2005) speaks to the importance of a counselor's ability to utilize an ethical decision making process such as those described by Forester-Miller and Davis's (1996), noting that ethical issues around maltreatment generally do not have clear answers.

By nature of their multifaceted professional role, school counselors may contribute in both direct and indirect ways to ensure that schools act in accord with legal and ethical mandates and use their role to promote broader and more effective advocacy interventions for maltreated children (Lambie, 2005). In the role of social justice advocates, counselors are ultimately called to collaborate with stakeholders to create a path that both respects the differing organizational 
priorities and agendas and affords best opportunities to best serve the needs of maltreated children.

One example of potential collaboration with community stakeholders would be for Counselor advocates to create and implement mandatory training programs for all members of the school community (Hinkelman \& Bruno, 2008; Kenny, 2004) that also included members of child protective services and lawyers adjudicating such cases. Cerezo and Pons-Salvador (2004) found that programs designed to enhance detection of abuse could be successful in school settings, and that exposure to training tripled detection rate, thus demonstrating the counselor's potential to effect change at the school or systems level.

\section{Commitment to Empowerment}

The third element of an advocacy disposition (Trusty and Brown, 2005), family empowerment, is similar to the client-student empowerment level of advocacy intervention articulated in the Advocacy Competencies (Lewis et al., 2002). Counselors disposed towards advocacy must aim to support and empower the families as well the children they serve. The counselor advocate working with maltreated children and their families needs to focus on strengths, including supporting the development of needed skills and the development of a positive sense of self. For example, a strengths-focus would support a mother's decision to act to protect her children from further abuse. In first helping her understand her actions from the context of her own character strengths including courage, nurturance, and power, a counselor can then assist her in using those strengths to forge a path to healthier functioning for her family. Counselors can join with parents in the process of identifying and naming existing systemic barriers, thus increasing self-efficacy and promoting awareness of the potential for change in the larger systemic level. School counselor advocates focused on family empowerment can help families view their difficulties in context, thus minimizing self-blame. In addition, families can learn how to use their strengths to address issues that may perpetuate their problems. From a systems advocacy perspective, empowerment includes assisting individuals in recognizing and addressing the socio-political barriers to healthier functioning and responding with social action that creates change in the larger social or public arena.

\section{Social Advocacy Orientation}

The final disposition identified by Trusty and Brown (2005) is that of an orientation toward social advocacy that provides the overarching and guiding impetus for the school counseling profession. Such an orientation encourages the development of a big picture perspective on the obstacles, limitations, and inequities that disadvantaged populations face. This is similar to the Systems Advocacy perspective articulated in the Advocacy Competencies (Lewis et al., 2002) and to Toporek and Liu's (2001) description of advocacy as "action taken by a counseling professional to facilitate the removal of external and institutional barriers to clients' well-being." (p. 387). In working with maltreated children in schools, a social advocacy disposition is seen when school counselors' use their skills and talents to support change in broader social systems, policies, and laws. For example, a counselor might work toward the goal of improving educational experiences and outcomes for maltreated children in foster care by supporting laws regulating interaction between school and child protective services personnel. A collaborative educational initiative described by Zetlin et al. (2005) demonstrates counselors connecting child 
protective service agencies with schools to increase sensitivity of protective services workers relative to the educational status and needs of foster children.

\section{Applying Advocacy Dispositions to Practice}

The task of applying the advocacy dispositions to practice is not a simple one. As schools struggle to create effective and coordinated systems to respond to maltreatment concerns, the reality of inherent complexities, both within and between involved systems, can function to make a difficult task even more difficult. Being alert to this potential is an essential element in fashioning a proactive and ultimately, an effective advocacy response.

As a result of the scope of their professional role, school counselors are responsible to students, parents, professional colleagues, their school and community, and their profession (ASCA, 2003). The role is broad by nature, and includes activities associated with counseling at group and individual levels, as well as consultation and collaboration both in and outside of schools. ASCA's (2003) position statement on child abuse and neglect delineates the counselor's role as accurately understanding and identifying the maltreatment, and effectively responding at both the individual and systemic levels.

Notable here is the reality of transition in the perception and practice of school counseling professionals' roles. The difficulties inherent in moving from the traditional to transformed roles are seen in schools across the country as the practice of what a school counselor's professional practice should look like changes. As comprehensive school counseling shapes how counselors are expected to practice in schools, an advocacy lens adds a new dimension to one's professional identity and a new level of complexity to practice. In order to truly be advocates, school counselors must be willing to step outside of their comfort zone and customary professional identity that is rooted in acts of helping and of peacemaking as described by Bemak and Chung (2008). They must be willing to let go of the nice counselor syndrome as the role of social justice advocate may require uncomfortable challenges to traditionally held power structures and organizational strategies (Bemak \& Chung). However, a shift in perception of self and role is necessary for a counselor to truly be able to adopt the advocate role. A counselor in a school setting may hesitate to incite the administration's ire by questioning existing child abuse reporting policies, hesitant to be perceived as less than helpful, or even fear for their position. But, such fears must be successfully overcome if they are to accomplish their ultimate goals of advocacy to meet the needs of maltreated children. In order to be truly effective, counselors are charged with the task of helping administrators better understand the counselor's professional advocacy role, so that as Bemak and Chung suggest, they may make meaningful change in their school communities. Only when they are able to conquer the need to be seen as nice, can they really do so.

Next we will articulate how that role can be effectively operationalized using the ASCA National Model (2005) in combination with the Advocacy Competencies (Lewis, Arnold, House \& Toporek, 2002). This includes counselor' intervening both with and on behalf of students at the individual, school, and broader systemic levels (Crethar, 2010; Lewis et al., 2002; Ratts et al., 2007). 
The ASCA National Mode/ categorizes delivery of school counseling services into four domains: responsive services, curriculum, individual planning, and systems support (ASCA, 2005). The responsive services domain includes traditional counselor skills and activities such as counseling and consultation; the curriculum domain involves the implementation of a developmentally sensitive and responsive series of classroom presentations geared to support healthy development in academic, career, and personal-social arenas; the individual planning domain focuses on working with students to establish and reach desired goals; and, the systems support domain includes counselors' management activities, collaboration, and the coordination of internal and external resources (ASCA, 2005). In each service delivery domain, the infusion of maltreatment informed services offers opportunities for schools to empower and contribute meaningfully to the lives of maltreated children. When counselors are able to demonstrate the impact of their interventions, an entire school community is made aware that well-planned interventions result in measurable change (Stone \& Dahir, 2007).

\section{Individual Level}

On the individual level, empowerment of disadvantaged persons and populations is recognized as central in advocacy competencies (Lewis et al., 2002; Trusty \& Brown, 2005; Ratts, DeKruyf, \& Chen-Hayes, 2007; Crethar, 2010) and is especially crucial in work with maltreated children. Empowerment, as described above, begins with recognition of existing strengths, and their applicability in facing and overcoming obstacles. Peterson (2006) speaks to the value inherent in working with clients to identify and discover ways to more broadly use important character strengths described from the perspective of clusters of like internal strengths, including those related to knowledge and wisdom; courage, humanity, and justice; temperance; and transcendence. Masten and Reed (2005) describe factors associated with fostering resilience that include working to identify and build protective factors. Supporting the development and use of protective factors offers invaluable opportunities to boost self esteem, enhance self efficacy and personal power, and increase hopeful expectations about the future. Among the population of children at-risk, efforts to promote resiliency are particularly critical (Galassi \& Akos, 2004). Families suffer enormous stress as a consequence of abuse allegations coming to light, and a strengths-focused, resilience building perspective assists in the transition to healthier functioning.

In the responsive services domain (ASCA, 2005), children are become empowered when they acquire skills necessary for identifying and overcoming obstacles at personal and systemic levels. Counselors can help empower maltreated children by assisting in their development of assertive communication skills. For example, a school counselor might enact their advocacy role by establishing an Empowerment-focused Group and intentionally include children who have experienced maltreatment for whom establishing these skills is consistent with an important area of need. In focusing on developing assertive communication skills, knowledge of group dynamics, and skills of mediation and problem solving, students could gain tools that last long beyond the end of the school years.

Advocacy-informed counselors also appreciate the inherent lack of control by children and families in the abuse intervention process and can empower them through education about the process, as well as by maximizing their involvement in choices. The counselor who advocates for a child's opportunity to voice preferences during a report and investigation process is 
providing an opportunity for that child to use their voice and experience a sense of power. In consultation, acting on behalf of the maltreated child, a counselor's work with teachers can further work to foster self-efficacy as well as provide information needed to eliminate obstacles to learning. In the individual planning domain, the school counselor working with a maltreated child recognizes that multiple foster placements may have limited opportunities to connect with a school counselor to establish an academic and life plan, and therefore might afford extra time for work in this area. For the maltreated child, establishing such goals may offer a measure of hope and foster needed belief in the promise of the future.

Also at the individual level, we see the need for proactive advocacy related to bureaucratic processes that often interfere with maltreated children receiving needed services. For example, there is often a legendary delay of transfer of educational records due to both within and between system factors that can cause a child to lose educational progress. Children in the foster care system are especially prone to suffer from lost or misplaced educational records. Therefore, scheduling regular check-ins with case workers or child protective service workers is of particular importance in assuring that educational needs are being met. In this advocacy role, the counselor helps ensure that paperwork and other bureaucratic challenges are not obstacles to service for an individual child.

\section{School Level}

On the school level, counselors use advocacy skills to identify areas of needed changes both within the school system and in relationships between the school and agencies, or providers of counseling services (Lewis et al., 2002). All of these are part of systems support in the language of the ASCA National Model (2005). School counselors act as advocates when they establish collaborative relationships with professionals in and outside the school community to build a system for more coordinated interventions on behalf of maltreated children. Lambie's (2005) model offers an example of a systemic school advocacy intervention. It includes a coordinated and comprehensive child abuse response system by establishment of a multidisciplinary team that develops maltreatment-informed policy and monitors practice. In crafting the guidance curriculum, school counselors can enact advocacy by being sensitive to the special areas of needs of maltreated children and intentionally weaving responses to these into the curriculum. These might include classroom lessons focused on interpersonal skills and assertive communication, management of emotions, development of self-efficacy, and attending and organizational skills, all of which are important areas of focus for maltreated children (Cole et al., 2005). The counselor's role as an advocate for maltreated children at the school level can be seen in collaborative efforts to create a safe school climate. Because multiple sources of victimization function to exacerbate a child's problems (Arata et al., 2007), maltreated children need to feel safe and protected in school if they are to learn (Cole et al., 2005). School-wide programs to reduce bullying and promote positive social behaviors offer another way in which the broader school environment can be changed as a result of the counselor's advocacy efforts, thus dramatically enhancing the educational experience of maltreated children in school.

The challenge of fostering needed change to longstanding policies and procedures within school systems is seen clearly in the efforts of the advocacy focused counselor to proactively identify and address those systems that perpetuate inequities and thus where change in existing decision making and power structures is essential. Again, the inherent complexity and 
inequities within a given system can often function as obstacles to identified goals of advocacy and social justice. The counselor advocate, in collaboration with stakeholders, must take on the task of challenging internal structures of power and decision-making and assist those in positions of power see different goals - the justifiable need for fashioning a different response or method of operation. This is indeed a challenge for school counselors who might be stuck in more traditional definitions of their role or reluctant to give up the nice counselor persona (Bemak \& Chung, 2008). Skilled counselor advocates will help all parties see the benefits they will reap from cooperation and collaboration to promote equity, and most importantly, how those efforts will better serve maltreated children. When this can happen, new systems, policies, and structures can be established allowing us to better meet the needs of maltreated children from the perspective of policy and procedure.

Finally, in considering the reality that any interaction between systems can be rife with potential for conflicting organizational needs, policies, and agendas, and that the sheer complexity within and between systems can result in the creation of obstacles to our goal of best serving maltreated children, the role of the school counselor as advocate is challenging at best. Griffin and Steen (2011) note that collaboration between stakeholders across disciplines is essential and that identifying the collaborative relationship developed between counselors and counselor education programs can be especially fruitful. Yet, even in these positive collaborative relationships, one needs to appreciate the potential impact of within and between system complexity, as the differing requirements of involved systems have the potential to clash and inadvertently serve as an obstacle to progress. An example might be seen in a school's need for data collection and the more stringent research related requirements of the university system. In one school, for example, completion of a bullying survey by a university affiliated individual required a signed and detailed informed consent from every parent. This is in contrast to the school's usual policy of sending out a form notifying parents that a survey would be administered and inviting their contact if they preferred that their child not participate. Requiring an affirmative response from parents presented an extra layer of challenge in affording children the opportunity to voice their experience and opinion, and ultimately reduced participant numbers. Thus, both the potential and the inherent challenge of establishing collaborative relationships are very real and require the proactive development of equitable practices. The school counselor is called to identify these places of difference and conflict and to work proactively to forge a path around the obstacles. Even when collaborative relationships are well established and common goals identified, there is still the possibility that complexity within a given system can function to impede progress toward advocacy focused goals.

\section{Broader Systems Level}

A counselor's advocacy role in the larger systems of public and social domains offers further opportunities to effect meaningful systemic change for maltreated children. Such a program might include counselors developing public informational programs (Lewis et al., 2002) that address both the impact of maltreatment on development, as well as the identification of protective factors. In the context of the Systems Support domain (ASCA, 2005), a school counselor is enacting their advocacy role when they bring together a multidisciplinary team to be broadcast on local cable affiliate channels. Such a panel might discuss and provide information on how the existing social structures are inequitable and unjust and may perpetuate childhood maltreatment. Such an action may be the first step in removing such obstacles by 
putting information in the reach of parents and others who otherwise would be unable to access it.

An advocacy perspective encourages school counselors to identify the obstacles that have historically prevented schools as institutions from taking advocacy roles (Bemak \& Chung, 2005). As noted by Crethar (2010), school counselors have the potential to join together to collectively support legislation that aims to effectively support student development in academic, personal/social, and career domains. School counselors can initiate or support legislation requiring all persons serving in mandated reporting roles to demonstrate an adequate grasp of maltreatment-related knowledge as part of professional certification or licensure. In this way, recognition and response to a child's maltreatment can become more appropriate, and counselors can broaden their understanding of measures to reduce obstacles that inhibit healthy development and school success for maltreated children.

Finally, it is important to note the potential for truly transformative change that emerges as smaller changes take place. Counselor advocacy that includes empowerment focused interventions that foster the development of healthy interpersonal and conflict management skills has the potential to reverberate into the future and ultimately interrupt intergenerational transmission of patterns of familial violence. At the school level, advocating for the development and implementation of better protocols to enhance recognition and response to maltreatment offers the possibility to enable earlier and potentially more effective interventions, and provides opportunities to engage and empower families in new ways. In addition, Advocacy focused interventions have the potential to reach far beyond work with individual school children and their families to also impact the social and political structures that function to perpetuate problems. Discovering unrealized strengths and learning the skills of advocacy at both a personal and broader systems level may help children develop into politically engaged and conscious adults, be able to use their power, and voice to effect needed change in the broader sociopolitical arena. As Marbley et al. (2011) would assert, it truly does take a village to address this challenge, which extends from supporting positive change from the individual to broadest sociopolitical levels.

\section{Conclusion}

Shocking numbers of maltreated children sit in classrooms across the United States and face serious obstacles to healthy development and school success. A social justice-inspired advocacy perspective understands maltreated children are a disadvantaged, often unseen and therefore underserved population. Utilizing the lens of advocacy dispositions as described by Trusty and Brown (2005) in combination with the Advocacy Competencies (Lewis et al., 2002), we have provided a lens and numerous examples for counselors in schools to work with the disadvantaged population of maltreated children and their families. Future work could extend beyond these two models to the development of a new and transformative model that broadens the frame to include changing those systems that support and perpetuate injustice and inequity in society. 
Contact Information/Correspondance :

Kathleen Marie Barrett, Ed.D.

Assistant Professor of Counseling Education

Saint Joseph College

Email : kbarrett@sjc.edu

\section{References}

altruism. (2010). In Merriam-Webster Online Dictionary. Retrieved January 10, 2010, from http://www.merriam-webster.com/dictionary/altruism

American Counseling Association. (2005). ACA code of ethics. Retrieved from http://www.counseling.org

American School Counselor Association. (2005). The ASCA national model: A framework for school counseling programs (2nd ed.). Alexandria, VA: Author.

American School Counselor Association. (2004a). ASCA national standards for students. Alexandria, VA: Author.

American School Counselor Association. (2004b). Ethical standards for school counselors. Alexandra, VA: Author.

American School Counselor Association. (2003). The professional school counselor and child abuse and neglect prevention. Retrieved from www.schoolcounselor.org

Arata, C. M., Langhinrichsen-Rohling, J., Bowers, D., \& O'Brien, N. (2007). Differential correlates of multi-type maltreatment among urban youth. Child Abuse and Neglect, 31, 393-415. Retrieved from http://www.ispcan.org

Bemak, F., \& Chung, R. (2005). Advocacy as a critical role for urban school counselors: Working toward equity and social justice. Professional School Counseling, 8, 196-202. Retrieved from http://www.schoolcounselor.org

Bemak, F. \& Chung, R.C-Y. (2008). New professional roles and advocacy strategies for school counselors: A Multicultural/social justice perspective to move beyond the nice counselor syndrome. Journal of Counseling \& Development, 86, 372-382.

Bluestone, C. (2005). Personal disciplinary history and views of physical punishment: Implications for training mandated reporters. Child Abuse Review, 14, 240-258. doi:10.1002/car.901

Bryant, J. (2009). School counselors and child abuse reporting: A national survey. Professional School Counseling, 12, 333-342. Retrieved from http://www.schoolcounselor.org 
Bryant, J., \& Milsom, A. (2005). Child abuse reporting by school counselors. Professional School Counseling, 8, 63-71. Retrieved from http://www.schoolcounselor.org

Bynum, L., Grifin, T., Ridings, D.L., Wynkoop, K.S., Anda, R.F., Edwards, V.J., ...Croft, J.B. (2010). Adverse childhood experiences reported by adults - Five states, 2009. Morbidity \& Mortality Weekly Report,;59(49):1609-1613.

Campbell, C. A., \& Dahir, C. A. (1997). Sharing the vision: The national standards for school counseling programs. Alexandria, VA: American School Counselor Association.

Cerezo, A., \& Pons-Salvador, G. (2004). Improving child maltreatment detection systems: A large-scale case study involving health, social professionals. Child Abuse and Neglect, 28, 1153-1169. Retrieved from http://www.ispcan.org

Cole, S., O'Brien, J., Gadd, M., Ristuccia, J., Wallace, D., \& Gregory, M. (2005). Helping traumatized children learn: Supportive school environments for children traumatized by family violence. Boston: Massachusetts Advocates for Children. Retrieved from http://www.massadvocates.org

Crethar, H. C. (2010). School counseling and advocacy competence. In Toporek, R. L., Lewis, J., \& Ratts, M. (Eds.) The advocacy competencies: A social justice framework for counselors. Alexandria, VA: American Counseling Association.

Crosson-Tower, C. (2008). Understanding child abuse and neglect. ( $7^{\text {th }}$ Ed.) Boston: Pearson Education.

Education Trust. (2009). Transforming school counseling. Retrieved from www.edtrust.org

Erford, B. F. (Ed.). (2003). Transforming the school counseling profession. Upper Saddle River, $\mathrm{NJ}$ : Pearson Education.

Evans, E., Hawton, K., \& Rodham, K. (2005). Suicidal phenomena and abuse in adolescents: A review of epidemiological studies. Child Abuse and Neglect, 29, 45-58. doi:10.1016/j.chiabu.2004.06.014

Forester-Miller, H., \& Davis, T. (1996). A practitioner's guide to ethical decision making. Alexandria, VA: American Counseling Association.

Galassi, J.P., \& Akos, P. (2004). Developmental advocacy: Twenty-first century school counseling. Journal of Counseling and Development. 146-157.

Goodman, J. (2009). Starfish, salmon, and whales: An introduction to the special section. Journal of Counseling and Development, 87, 259. Retrieved from http://www.counseling.org

Griffin, D., \& Steen, S. (2011). A social justice approach to school counseling. Journal for Social Action in Counseling and Psychology, 3, 1, 74-85. 
Hermann, M. A. (2002). A study of legal issues encountered by school counselors and their perceptions of their preparedness to respond to legal challenges. Professional School Counseling, 6, 12-19. Retrieved from http://www.schoolcounselor.org

Hinkelman, L., \& Bruno, M. (2008). Identification and reporting of child sexual abuse: The role of elementary school professionals. The Elementary School Journal, 108, 376-391. doi: $10.1086 / 589468$

Kaplow, J. B., \& Widom, C. S. (2007). Age of onset of child maltreatment predicts long-term mental health outcomes. Journal of Abnormal Psychology, 116, 176-187. doi:10.1037/0021-843X.116.1.176

Kenny, M. (2004). Teachers' attitudes toward and knowledge of child maltreatment. Child Maltreatment, 28, 1311-1319. Retrieved from http://www.apsac.org

Kernic, M. A., Wolf, M. E., Holt, V. L., McKnight, B., Huebner, C. E., \& Rivara, F. (2003). Behavioral problems among children whose mothers are abused by an intimate partner. Child Abuse and Neglect, 27, 1231-1247. doi:10.1016/j.chiabu.2002.12.001

Lambie, G. (2005). Child abuse and neglect: A practical guide for professional school counselors. Professional School Counseling, 8, 249-258. Retrieved from http://www.schoolcounselor.org

Lee, C. C. (2007). Social justice: A moral imperative for counselors (ACAPCD-07). Alexandria, VA: American Counseling Association.

Lee, C. C., \& Rodgers, R. A. (2009). Counselor advocacy: Affecting systemic change in the public arena. Journal of Counseling and Development, 87, 284-287. Retrieved from http://www.counseling.org

Lewis, J. A., Arnold, M. S., House, R., \& Toporek, R. L. (2002). ACA advocacy competencies. Retrieved from http://www.counseling.org.

Lopez-Baez, S. I., \& Paylo, M. J. (2009). Social justice advocacy: Community collaboration and systems advocacy. Journal of Counseling and Development, 87, 276-283. Retrieved from http://www.counseling.org

Marbley, A., Malott, K., Flaherty, A., \& Frederick, H. (2011). Three issues, three approaches, three calls to action: Multicultural social justice in the schools. 3, 1, 59-74 (check pg)

Masten, A.S., \& Reed, M. (2005). Resilience in development. In Snyder, C., \& Lopez, S. (Eds.), Handbook of positive psychology, 74-88. New York, NY: Oxford University Press.

Middlebrooks, J. S., \& Audage, N. C. (2008). The effects of childhood stress on health across the lifespan. Atlanta, GA: Centers for Disease Control and Prevention, National Center for Injury Prevention and Control.

Miller-Perrin, C. \& Perrin R. (2007). Child Maltreatment: An Introduction (2 ${ }^{\text {nd }}$ Ed.).Thousand Oaks, CA: Sage. 
National Clearinghouse on Child Abuse and Neglect Information. (2005). Long term consequences of child abuse and neglect. Retrieved from http://www.childprotectionoffice.org

Peterson, C. (2006). A primer in positive psychology. New York, NY: Oxford University Press.

Pears, K., Kim, H., \& Fisher, P. (2008). Psychosocial and cognitive functioning of children with specific profiles of maltreatment. Child Abuse and Neglect, 32, 958-971. doi:10.1016/j.chiabu.2007.12.009

Perez, C. M., \& Widom, C. (1994). Childhood victimization and long-term intellectual and academic outcomes. Child Abuse and Neglect, 1, 617-633. doi:10.1016/01452134(94)90012-4

Perry, B. D. (2001). The neurodevelopmental impact of violence in childhood. In Schetky, D., \& Benedek, E. (Eds.), Textbook of child and adolescent forensic psychiatry (pp. 221-238). Washington, DC: American Psychiatric Press.

Ratts, M. J., \& Hutchins, A. M. (2009). Social justice advocacy: Community collaboration and systems advocacy at the client/student level. Journal of Counseling and Development, 87, 269-275. Retrieved from http://www.counseling.org

Ratts, M. J., DeKruyf, L., Chen-Hayes, S. F. (2007). The ACA advocacy competencies: A social justice advocacy framework for professional school counselors. Professional School Counseling, 11. 90-97. Retrieved from http://www.schoolcounselor.org

Reynolds, M. W., Wallace, J., Hill, T. A., Weist, M. D., \& Nabors, L. A. (2001). The relationship between gender, depression, and self-esteem in children who have witnessed domestic violence. Child Abuse and Neglect, 25, 1201-1206. doi:10.1016/S0145-2134(01)00269-1

Rowe, E., \& Eckenrode, J. (1999). The timing of academic difficulties among maltreated and nonmaltreated children. Child Abuse and Neglect, 23, 813-832. doi:10.1016/S01452134(99)00044-7

Silverman, A. B., Reinherz, H. Z., \& Giaconia, R. M. (1996). The long-term sequelae of child and adolescent abuse: A longitudinal community study. Child Abuse and Neglect, 20, 709723. doi:10.1016/0145-2134(96)00059-2

Stone, C. (2005). School counseling principles: Ethics and law. Alexandria, VA: American School Counselors Association.

Stone, C. B., \& Dahir, C. A. (2007). School counselor accountability: A MEASURE of student success. (2nd ed.). Upper Saddle River, NJ: Pearson/Merrill Prentice Hall.

Sue, D. W., Arredondo, P., \& McDavis, R. J. (1992). Multicultural counseling competencies and standards: A call for the profession. Journal of Counseling and Development, 70, 477486. Retrieved from http://www.counseling.org 
Teicher, M. D. (2000). Wounds that time won't heal: The neurobiology of child abuse. Cerebrum: The Dana Forum on Brain Science, 2, 50-67. Retrieved from http://www.dana.org

Toporek, R. L., Lewis, J. A., Crethar, H. C. (2009). Promoting systemic change through the ACA advocacy competencies. Journal of Counseling and Development, 87, 260-268. Retrieved from http://www.counseling.org

Toporek, R. L., \& Liu, W. M. (2001). Advocacy in counseling: Addressing race, class, and gender oppression. In D. B. Pope-Davis \& H. L. K. Coleman (Eds.), The intersection of race, class, and gender in multicultural counseling (pp. 285-413). Thousand Oaks, CA: Sage.

Trusty, J., \& Brown, D. (2005). Advocacy competencies for professional school counselors. Professional School Counseling, 8, 259-265. Retrieved from http://www.schoolcounselor.org

U.S. Department of Health and Human Services, Administration on Children, Youth and Families. (2006). Child maltreatment 2006. Washington, DC: U.S. Government Printing Office.

U.S. Department of Health and Human Services, Administration for Children and Families, Administration on Children, Youth and Families, Children's Bureau. (2010). Child Maltreatment 2009. Retrieved from http://www.childwelfare.gov/systemwide/statistics/can/stat_natl_state.cfm

Walsh, K., Bridgstock, R., Farrell, A., Rassafiani, M., \& Schweizer, R. (2008). Case, teacher and school characteristics influencing teachers' detection and reporting of child physical abuse and neglect: Results from an Australian survey. Child Abuse and Neglect, 32, 983993. doi:10.1016/j.chiabu.2008.03.002

Webster, S. W., O'Toole, R., O'Toole, A. W., \& Lucal, B. (2005). Overreporting and underreporting of child abuse: Teachers' use of professional discretion. Child Abuse and Neglect, 29, 1281-1296. doi:10.1016/j.chiabu.2004.02.007

Widom, C. S. (2000). Understanding the consequences of childhood victimization. In R. M. Reece (Ed.), Treatment of child abuse (pp. 339-361). Baltimore, MD: Johns Hopkins University Press.

Widom C. S., Marmorstein, N., \& White, H. (2006). Childhood victimization and illicit drug use in middle adulthood. Psychology of Addictive Behaviors, 20, 394-403. doi:10.1037/0893164X.20.4.394

Widom C. S., \& Maxfield M. G. (2001). An update on the "cycle of violence. "Washington, DC: National Institute of Justice.

Wodarski, J., Kurtz, P., Gaudin, J., \& Howling, P. (1990). Maltreatment and the school-age child: Major academic, socioemotional, and adaptive outcomes. Social Work, 35, 506513. Retrieved from http://www.naswpress.org 
Yoshihama, M., \& Mills, L. G. (2003). When is the personal professional in public child welfare practice? The influence of intimate partner and child abuse histories on workers in domestic violence cases. Child Abuse and Neglect, 27, 319-336. doi:10.1016/S01452134(03)00009-7

Zetlin, A., Weinberg, L., \& Kimm, C. (2005). Helping social workers address the educational needs of foster children. Child Abuse and Neglect, 29, 811-823. Retrieved from http://www.ispcan.org 